\title{
Functional and pragmatic value of nonverbal communication in conflict fiction discourse
}

\author{
O. V. Chernenko \\ Kyiv National Linguistic University, Kyiv, Ukraine \\ Corresponding author. E-mail: ukrum2013@gmail.com \\ Paper received 09.11.19; Accepted for publication 21.11.19.
}

\begin{abstract}
https://doi.org/10.31174/SEND-Ph2019-212VII63-03
\end{abstract}
\begin{abstract}
The article focuses on the study of nonverbal means of communication in conflict discourse within the framework of pragmatic studies. The paper describes the pragmatic and functional peculiarities of nonverbal module in the structural organization of conflict fiction discourse. Some of the mechanisms and important factors by which nonverbal means of communication can be structured and classified are reviewed. Pragmatic value of nonverbal means of communication in conflict discourse resolution is
\end{abstract} studied.

Keywords: conflict discourse, final conflict interaction phase, illocutionary force, perlocutionary effect, verbal and nonverbal means of communication, nonverbal module.

Introduction. In recent years, the analysis of different types of discourse has become an inherently interdisciplinary domain of research comprising a wide range of methods and approaches for explaining language in use. Conflict discourse being a complex multidimensional phenomenon that always exists in context brings to light the necessity to address its various dimensions, i.e. the cognitive, the social, the intertextual, the situational, the linguistic ones, including pragmatic approaches as special means for the full interpretation of a speaker's verbal and nonverbal behaviour in conflict communicative situation.

The importance of nonverbal cues interpretation in different communicative situations cannot be underestimated today. According to M. Knapp and J. Hall, more than 65 percent of a message's social meaning is carried nonverbally [12, p. 15]. The nonverbal level of communication helps us to define the nature of each relationship we share, which is important in everyday interpretation data in general and in conflict communication in particular [7; $18]$.

The structural organization of nonverbal messages in conflict discourse is characterized by a complex of its locative, communicative, nominative and functional aspects, which help to reveal the main pragmatic peculiarities of their use and functioning in fiction conflict discourse.

Review of publications. Linguistic analysis of nonverbal means of communication in modern studies is characterized by communicative and functional approach to the study of somaticon of English nonfictional and fictional discursive practices [18], nominative, communicative, and pragmatic aspects of the speaker's tactile behaviour in the English fictional discourse [21], verbal and nonverbal aspects of culture of communication [14], nonverbal means of expressing empathy in English dialogical discourse [11], nonverbal peculiarities of the speaker's invective behavior in conflict discourse [22], gender aspects of haptic communication [8], the study of pragmatic functions of gestures [9], visual speech segmentation study [17], etc.

The objective of this article is to complete a theoretical framework of conflict discourse studies by revealing pragmatic peculiarities and communicative value of the nonverbal means of communication in conflict fiction discourse. It is achieved by fulfilling the following tasks:

(i) to outline classification of various aspects of nonverbal communication, (ii) to establish the main features of verbal and nonverbal module in conflict discourse, (iii) to systematize pragmatic peculiarities of discourse representation of the final phase in conflict interaction, (iv) to study nonverbal means of communication in the final phase of conflict interaction, ( $v$ ) to reveal pragmatic and functional peculiarities of the use of linguistic and extra linguistic means in conflict fiction discourse.

Methods and material. To achieve the aim of the research and accomplish its tasks, a number of general scientific methods, such as analysis and synthesis, induction and deduction, as well as methods of linguistic analysis, such as contextual, modular method, pragmatic and discourse analysis and elements of the quantitative analysis method are used.

The research material comprises discursive fragments, singled out from fictional discourse, with a specific focus on everyday communicative situations of conflict communication, predominantly selected from the works of British and American authors of the 20th-21st century (a total volume of about 3000 pages).

Results and discussion. Nonverbal means of communication in conflict communication serve as inseparable part of the process of interaction and are characterized by high informative value as well as valuable information taken from the complex of other extra linguistic factors, influencing the process of conflict discourse development.

The majority of scholars classify the main nonverbal means of communication into the following groups according to the place of their realization:

1). the use of the body (kinesics), which includes gestures and body language;

2). the use of the space in communication (proxemics), when space determines how comfortable communicants feel talking to each other;

3 ). the use of the voice (paralinguistics), which carries both intentional and unintentional messages of the speaker;

4). the use of the face (facial signals), which includes facial expression and eye contact, the primary site for the expression of emotion, revealing the type and intensity of a person's feelings;

$5)$. the use of the touch (haptics), or touching behavior/tactile communication, which is an important vehicle 
for conveying comfort, reassurance and can create either positive or negative effect in communication $[1 ; 12 ; 13$; $18 ; 21]$.

As the analysis of conflict discursive fragments shows, a wide range of nonverbal means of communication is used in conflict fiction discourse: kinetic, proxemics, body language and gestures, haptics, facial expression and vocal characteristics, which are used not only to add, regulate or emphasize verbal messages but also to mitigate or even neutralize the illocutive polysemy of utterances, revealing true interpretation of speaker's feelings and intentions, e.g., "How stupid of you, Zoya! I can't understand why you would go there. Do you wish to catch the measles?" "No, Mama. I'm truly very sorry."

But there was nothing in her face to make one believe that she was [19, p. 27].

In the above-mentioned fragment the nonverbal cue but there was nothing in her face, fixed in author's remark, gives the explication of the true meaning of the utterance. By paying attention to these nonverbal cues a researcher can also detect deception or affirm speaker's honesty in conflict communication.

Communicative value of nonverbal means of communication in conflict fiction discourse may be represented by the following aspects:

1). pragmatic force of the utterance;

2). perlocutionary effect on the speaker;

3). functioning.

Communicative intentions of the speaker in conflict fiction discourse are realized through five main conversational strategies, characterizing the illocutionary force of the utterances, when the communicants tend to compete or cooperate in order to achieve their goals: 1) competing, a counterproductive conflict strategy, a competitive orientation to the conflict, 2) avoiding, a counterproductive conflict strategy, an unassertive approach to the conflict, 3) accommodating, a counterproductive conflict strategy, resolving the conflict at the expense of one side, 4) compromising, a productive conflict strategy, an acceptable settlement of the conflict for both sides, 5) collaborating, a productive conflict strategy, an attempt to find a win-win solution $[7 ; 15 ; 16 ; 20]$.

In the process of conflict discourse development we distinguish three groups of nonverbal conflictmanagement modes, which regulate and govern conflict interaction in fiction discourse and help to realize main conversational strategies: 1) physical, which comprises tactile communication, gestures, body language, such as fighting, tussle, scramble, pushing, kick, smack in the face, etc., e.g., His other hand slipped behind her neck, keeping her locked in his rough embrace. Stephanie defiantly turned to face him. "You've been reading too many gossip columns, Mr. Steel.” [2, p.128]; 2) psychological, including the relationship pressure, such as cry, threats, orders, realized through the posture, gaze, voice, gestures, e.g., His thin, lean hands clenched and he clicked his teeth. "Mine, mine, mine!" he muttered, and one would have thought him a villain in a cheap melodrama. Mrs. Dale shook her head [6, p.621]; 3) behavioral, comprising refusal, instructions to the partner, suppression of emotions, e.g., "Don't be foolish, Margy," he said, seeing the ill wind he had aroused. "You don't mean that." "Don't I? Well, we'll see." She walked away from him to another corner of the room. He followed her, but her anger re-aroused his opposition. "Oh, all right," he said after a time. "I guess I'd better be going. "She made no response, neither pleas nor suggestions. He went and secured his hat and coat and came back [6, p.46].

As a result, these conflict-management strategies, realized in the aftermath stage of conflict by verbal and nonverbal means of communication, serve as pragmatic tools to achieve different communicative intentions of the speaker and to express a wide range of emotions from anger to sadness. They create a definite perlocutionary effect, resulting in harmonization, disharmonization or pseudo-harmonization (conflict suppression) of relations between communicants. Accordingly, three communicative types of ending the conflict are distinguished: disconnection, which leads to disharmonization of interpersonal relations, and ends in physical or verbal violence; reconciliation, which leads to harmonization of interpersonal relations, and ends in settlement of a conflict situation; accommodation, which leads to pseudoharmonization of interpersonal relations, and ends in waning of conflict communication.

Nonverbal means of communication is strongly related to verbal communication. According to the modular method, a speech act can be formalized as an interrelation of two modules: verbal and nonverbal, e.g., "They're dead and buried", (verbal module) she said, her voice trembling (nonverbal module) [10, p. 164]. Applying the modular method, the study employs the definition of the key characteristics of nonverbal module, its correlation with the verbal module in terms of its informative, semantic, pragmatic and functional value, the peculiarities of the inner structure of nonverbal part of speech act.

The structural characteristics of nonverbal module in conflict fiction discourse comprise eight types of nonverbal cues, organized due to nominative, locative and functional criteria. On the basis of nominative criteria, mononominative, e.g., "Have you changed your mind?" "Yes, I think I have." He looked at her dramatically [6, p. 34], and multinominative types are differentiated, e.g., Her face was white, her hands clenched, her teeth set. She had a keen, savage beauty, much like that of a tigress when it shows its teeth. Her eyes were hard and cruel and flashing [6, p. 608].

According to the locative criterion, nonverbal modules in conflict fiction discourse are classified into initial, medial and final types. Consider the following fragment of conflict discourse: Micah lost it then. Eyes blazing, he shouted, "If she was, I don't know where! I don't fuckin' know where! Do you think that makes me feel good?" $\underline{A}$ dead silence followed the outburst. In its midst, Griffin caught the smallest movement in the corner of his eye. Glancing back at the door, he saw Poppy. Her eyes were on Micah. She looked devastated. Griffin let out a breath. "No, I don't suppose it does," he said quietly. He glanced at Poppy again, but she continued to look at Micah. Discouraged, he said, "I've done enough for today, I guess," and let himself out the back door [5, p. 179-180].

In the above-mentioned fragment the nonverbal module, used in preposition, medial position and postposition, modifies the verbal messages in conflict interaction, emphasizing and strengthen the verbal module. 
Observed from the conflict fiction discourse fragments analysis, nonverbal means of communication may serve as independent means of communication, substituting the verbal messages; they may also strengthen or complete their meaning, or add new meaning to the verbal message, containing opposition, contradiction, and contrast. Therefore, the nonverbal module represents different functions in conflict fiction discourse, which can be grouped in the following functional types: substitutional, complementary and oppositive.

The first group of nonverbal cues, substitutional, is represented mostly by kinetic means of communication, fixed in author's remarks let himself out the back door, she walked away from him to another corner of the room, the door slammed with a resolute bang, then his eyes dropped, he turned out and walked out etc. These nonverbal messages are often added by the communicative act of silence, which is meaningful in conflict communication as well as other substitutional nonverbal cues, serving to nominate strong negative emotions in competitive type of conflict communicative situation, mostly anger and irritation, e.g., He was astonished by the woman's determination, but it only irritated him the more.

"Well, we'll see about that..." "You talk as though you settled my affairs for me." He was thoroughly aroused now. His dark eyes snapped, and he crunched his paper as he laid it down. Mrs. Hurstwood said nothing more (6, p. 225).

The second group of nonverbal cues, complementary, is used to strengthen the verbal message emotionally, they are used both in the situations of disconnection and reconciliation of the communicants and are represented by kinetic, prosodic, proxemics nonverbal means his dark eyes snapped, eyes blazing, her eyes were on Micah, glancing back at the door, she turned to face him, he clicked his teeth, Mrs. Dale shook her head, he followed her etc. Consider the following example: "Why don't you come out and say it?" Josh suggested, his voice steel edged. "No." "Then I'll say it for you. Because I'm crippled, right, and so you feel the need to protect my tender sensibilities. That's in, isn't it?" Marta looked at him, outraged. "No," she stormed, heedless of other people in the bar. "That's not it at all. You're reading me all wrong. You've always read me all wrong, damn it!' Marta grabbed her handbag and slid out of the banquette in one swift motion [3, p. 129].
The third group of nonverbal cues, oppositive, is not a numerous one but the nonverbal means of communication, belonging to this group, help to differentiate between psychological and emotional state of communicants and the verbal messages they present. According to our observations, kinetic and prosodic means are used in this function; proxemics nonverbal cues are less commonly used in the function of opposition, e.g., "Perhaps if it lives in the kitchen...Perhaps then..." He looked hopefully at his wife, as she strode to the door and pulled it open. "You always give in to her, Konstantin, don't you?" "Darling, perhaps Grandmama would keep it at her house." He looked hopefully at his mother. She smiled, secretly enjoying the storm. "I'd be quite willing to have him," the Countess offered seriously. "Very well," Konstantin felt he had found the perfect solution, but the door slammed with a resolute bang, and he knew he wouldn't see his wife again until the next morning. [19, p. 35].

Despite of the serious tone of the conversation in the above-mentioned conflict situation and persuasive force of the verbal utterance, the Countess shows her ironic position to the quarrel between her son and his wife, which is reflected in kinetic nonverbal cue She smiled, secretly enjoying the storm.

Conclusions. Thus, the nonverbal means of communication in conflict fiction discourse play an important role in analysis, interpretation and exploring the conflict communicative situations. Taking into account the informative value of nonverbal messages, it is possible to analyze the total impact of messages, transmitted nonverbally in different communicative situations, including conflict discourse. Functional and communicative value of nonverbal module in fiction conflict discourse has been analyzed from the viewpoint of the modular method, representing the structural characteristics of nonverbal module as a complex of its nominative, locative and functional characteristics. Therefore, in conflict communicative framework, nominative criterion is represented by mononominative and multinominative structure of nonverbal module; due to the locative criterion, the nonverbal cues are classified into initial, medial and final types. Functional criterion in the structure of nonverbal module is represented by substitutional, complementary and oppositive nonverbal messages.

\section{ЛІТЕРАТУРА}

1. Argyle, M. Nonverbal communication in Human Social Interaction // Nonverbal Communication, 1972. Vol. 11 (3). P. $-243-268$.

2. Bowen, A. Dangerous Promise. - New York: Superromance, 1982. $-378 \mathrm{p}$

3. Charles, M. Diamond Moods. - New York: Silhouette Books, 1989. $-251 \mathrm{p}$

4. Черненко, О.В. Конверсаційні стратегії конфліктного дискурсу: Комунікативно-прагматичний аспект // Науковий вісник кафедри ЮНЕСКО Київського національного лінгвістичного університету. Філологія. Педагогіка. Психологія. Київ: Київський національний лінгвістичний університет, 37, с. 147-156.

5. Delinsky, B. An Accidental Woman. - New York: Pocket books, 2003. $-501 \mathrm{p}$.

6. Dreiser, T. Genius. - Moscow: Higher school publishing house, 1998. $-594 \mathrm{p}$.

7. Gamble, T.K. \& Gamble, M. Communication works. 11th ed. New York: McGraw-Hill Humanities/Social Sciences/Languages, 2012, $440 \mathrm{p}$.

8. Hertenstein, M., Keltner, D. Gender and the Communication of Emotion via Touch // Sex roles, 2011. Vol. 64. Issue 1-2. P. 70-80.

9. Kendon, A. Pragmatic functions of gestures: Some observations on the history of their study and their nature // gesture, 2018. Vol. 16. Issue 2. P. 157-175.

10. Kincaid, D. Trigger: A Morgan \& McCoy Chronicle. - New York: Lulu.com, 2010, 320 p.

11. Козяревич, Л. В. Вербальні й невербальні засоби емпатизації діалогічного дискурсу (на матеріалі англомовної прози XX століття): дис.... кандидата філол. наук: 10.02 .04 - германські мови. Київ: Київський національний лінгвістичний університет, 2006. - 191 с. 
12. Knapp, M., Hall, J. Nonverbal Communication in Human Interaction. - New York: Harcourt Brace College Publishers, 1997. $-270 \mathrm{p}$.

13. Крейдлин, Г.Е. Невербальная семиотика: Язык тела и естественный язык. - М.: Новое литературное обозрение, 2002. - $592 \mathrm{c}$.

14. Курило, О.Й., Розман, I.І. Вербальні та невербальні аспекти культури спілкування// Молодий вчений, 2017. №4.3 (44.3). C. 114-118.

15. Liddicoat, A. J. An introduction to conversation analysis. London: Continuum, 2007, 323 p.

16. Malki, I. Conflict resolution strategies in media Discourse: The case study // International journal of social science studies, 2018. Vol. 6. p. 24-35.

17. Mitchel, A.D., Weiss D.J. Visual speech segmentation: using facial cues to locate word boundaries in continuous speech // Language and Cognitive processes, 2014. Vol. 29. Issue 7. P. 771-780.

18. Сєрякова, I.I. Соматикон англомовних дискурсивних практик. Автореферат дисертації на здобуття вченого ступеня доктора філологічних наук. Спеціальність 10.02.04 - германські мови та 10.02.15 - загальне мовознавство. Київ: Київський національний лінгвістичний університет, 2012

19. Steel, D. The Gift. - New York: A Dell book, 1994. - 275 p.

20. Thomas, K.W., Kilmann, R.H. Thomas-Kilmann conflict mode instrument. New York: XICOM, 1990. - 20 p.

21. Жуковська, А.В. Тактильна поведінка мовця в англомовному художньому дискурсі: номінативний та комунікативно-прагматичний аспекти. Автореферат дисертації на здобуття вченого ступеня доктора філологічних наук. Спеціальність 10.02.04 - германські мови. Київ: Київський національний лінгвістичний університет, 2018.

22. Золотаренко, Т.О. Репрезентація інвективної поведінки мовця в конфліктному дискурсі (на матеріалі романів Стівена Кінга). Дисертація на здобуття вченого ступеня кандидата філологічних наук. Спеціальність 10.02 .04 германські мови. Київ: Київський національний лінгвістичний університет, 2015.

\section{REFERENCES}

4. Chernenko, O.V. Conversational strategies in conflict discourse: Communicative and pragmatic aspect // Scientific messenger of the UNESCO department of Kyiv National Linguistic University. Philology. Pedagogy. Psychology. Kyiv: Kyiv National Linguistic University, 2019. No. 37. p. 98106.

11. Kozyarevych, L. V. Verbal and nonverbal methods of empathy expression in dialogic discourse (on the material of English prose of XX century). Thesis for the candidate degree in philology. Speciality 10.02.04 - Germanic languages. Kyiv: Kyiv National Linguistic University. 2006. - 191 p.

13. Krejdlin, G.E. Nonverbal semiotics: body language and natural language. - Moscow.: Novoye literaturnoye obozreniye, 2002. $-592 \mathrm{p}$.

14. Kurylo, O.Y., Rozman, I.I. Verbal and nonverbal aspects of culture of communication // Young Scientist, 2017. №4.3 (44.3). P. 114-118.

18. Seryakova, I.I. Somaticon of English discursive practices. Synopsis for thesis for the doctor degree in philology. Specialty 10.02.04 - Germanic languages and 10.02.15 - general linguistics. Kyiv: Kyiv National Linguistic University, 2012.

21. Zhukovska, A.V. The Speaker's Tactile Behaviour in English Fictional Discourse: Nominative, Communicative, and Pragmatic Aspects. Synopsis for thesis for the candidate degree in philology. Specialty 10.02.04 - Germanic languages. Kyiv: Kyiv National Linguistic University, 2018.

22. Zolotarenko, T. O. Representation of the speaker's invective behaviour in conflict discourse (a study of the novels by Stephen King). Thesis for the candidate degree in philology. Speciality 10.02.04 - Germanic languages. Kyiv: Kyiv National Linguistic University, 2015. 